\section{International Scientific Journal Theoretical \& Applied Science}

Lazizjon Erkinovich Bahranov

Senior researcher

"Ethic and Aesthetic" Dept.

The Mirzo Ulugbek National University of

Uzbekistan

Tashkent, Uzbekistan

lazizorzu@gmail.com

Published: $30.01 .2016 \quad$ http://T-Science.org

SECTION 30. Philosophy.

\title{
THE QUESTIONS OF THE DEVELOPMENT OF THE NATIONAL IDEA AND ART CRITICISM IN UZBEKISTAN
}

\author{
Abstract: In this article some correlations between the national idea and art critics in Uzbekistan are \\ considered. The article also presents a comparative analysis of negative influences of social realism and positive \\ content of the concept of development of contemporary art in our country. \\ Key words: national idea, art criticism, art, Academy of arts of Uzbekistan, journal "SAN'AT", national \\ crafts, deideologization of art. \\ Language: English \\ Citation: Bahranov LE (2016) THE QUESTIONS OF THE DEVELOPMENT OF THE NATIONAL IDEA \\ AND ART CRITICISM IN UZBEKISTAN. ISJ Theoretical \& Applied Science, 01 (33): 106-109. \\ Soi: http://s-o-i.org/1.1/TAS-01-33-19 Doi: crossef http://dx.doi.org/10.15863/TAS.2016.01.33.19
}

Radical socio-political and economic transformations that began in 1991 opened a new page in the history of artistic culture of Uzbekistan. Thanks to the independence for a small historical period in the country had laid an unprecedented productive foundations for future development in the XXI century, there are created a fundamentally new political fundamentals of state and social structure of Uzbekistan. As a core value of landmark new cultural policy was declared the symbiosis of national and universal values. These two components gave the originality of modern aesthetic searches in the art of Uzbekistan.

The development of cultural and artistic processes of the early 1990s was largely determined by a number of socio-political and economic factors that accompanied the first steps of the young independent state. So, the country's foreign policy is inclusion of Uzbekistan in international organizations and establishing diplomatic relations with many countries as a subject of international law - has opened the "iron curtain" in the field of culture and art and let the creative intelligentsia of the country is not only deeply acquainted with the achievements of the modern world artistic process but to present the achievements of the national culture and art on the world stage. The membership in the UN, UNESCO and other international organizations initiated a number of significant projects in the field of education, culture and art, which are successfully implemented in Uzbekistan and gave impetus to the revival and development of spiritual culture of the nation.

In the sphere of economic policy Uzbekistan took a course on real sovereignty - achieving energy independence, the rise of national economy and overcoming the crisis faced by all the republics of the former USSR in the early 1990s. The development of the basic sectors of economy allowed the state to take responsibility for the fate of spiritual culture and to announce itself as the main sponsor of the reforms in the field of art.

An important factor in the development of art became an ideological component, which is reflected in the idea of national independence, objective interpret and evaluate their own historical heritage in building the prospects for further development of national culture and art.

From the first years of independence the cultural policy of Uzbekistan was aimed at establishing and improving of the spiritual realm to the study and propaganda of historical, moralreligious and cultural values.

The leading role of religion of the nation of Islam has been undergone to fair reassessment, there began to build mosques, madrasas, were established the conditions to make believers of the Holy Hajj. A new, objectively-historical point of view has been interpretated the activity of the Great Sahibkiran Amir Temur, who became the true national hero of the country. All these socio-historical factors largely determined the priorities and directions of cultural 
policies and contributed to a significant transformation in the art. This is exemplified by the development of national painting, philosophy of which was changed on the eyes. There were proclaimed freedom of artistic expression and the rejection of the dictates of state censorship on creativity. However, in difficult conditions of transition to the market, the state has reserved the economic support of culture and art.

In the second half of the 1990s were the institutional reforms implemented in various spheres of art and culture, aimed at strengthening the material-technical base, improvement of the organizational and creative structure of art. In the field of fine arts it was decided to create the Academy of arts of Uzbekistan. The main task facing the new organization was evident - to give impetus to the development of fine and applied art in a new historical situation, to create conditions for the emergence of national art of Uzbekistan in international cultural space as an independent artistic phenomenon. Improving the social status of the artist, his role in the establishment of a new society and spiritual culture are also important when considering the question of the establishment of the Academy of arts, which to a large extent determined by economic factors. An independent state during a difficult period of transition to market relations has announced that it takes responsibility for the fate of art and culture.

In the process of preparing of the project of the Academy of arts, architecture and the Statute was reviewed and taken into account the world experience of the historical and contemporary development of such organizations. The most optimal way seemed to create a strong government structure capable of consolidating artistic forces and giving new impetus to the development of the three main components of the creative process in art are art education, exhibition-creative activity, as well as research, critical and propaganda work. Such structure became the Academy of arts of Uzbekistan, established in accordance with the Decree of the President of the Republic of Uzbekistan Islam Karimov on January 13, 1997.

The most productive transformation proceeded in fine and applied art. If the development of traditional arts and crafts are more closely associated with the market, depended on the organizational and economic measures of the government (the removal of duties on export, strengthening the social status of craftsmen, the formation of new institutional structures and associations of folk craftsmen), then in the visual arts more important was the personal style and creative metamorphoses, in its own way reflecting the processes of social changes.

Along with a natural interest in their own traditional values to its rich artistic heritage, artists of Uzbekistan also perceive creatively the achievements of modern European and world art. This was especially evident in the national easel painting.

In the twentieth century in Uzbekistan has developed a very strong professional art school. Encountered by artists in the early 1990s, the feeling of creative freedom and maximum self-expression has changed the face of art. Unusual by its philosophy of the pictures concepts of the 1990s opposed to previous academic directions.

The socialist realism as a total method of the Soviet art passed on the top positions, but of the realistic school in art not left the scene prior to the impact of tradition is palpable in the art of the 1990s. At the same time keep new aspirations in art was impossible. The removal of the "iron curtain" has allowed Uzbek cultural figures to communicate directly with the creative experience and avant-garde phenomena of the contemporary art world, to focus their new creative experiments. The formation in Uzbekistan of new ideological priorities, based on the glorification of their own national history, has further increased the importance and relevance of memorial concepts in contemporary art. The socialgrotesque and socio-evaluative trends in the early 90ties lose their significance and actually come to naught. Phantasmagoria, a mixture of myths-epic and folklore and fairytale characters, stories, sacral-cultic symbols and signs that are included in new plastic canvas characterize this stage of development of painting.

In the 1990's in our country has developed a distinctive style, a group of artists aged from 35 to 60 years, which combines the search for new creative ideas and unflagging interest from the spectators and specialists. Their works have increased commercial demand.

The overall picture of the development of art during this period in a sense looks forked and often eclectic. On the one hand, intensified the modernist trends, search for new plastic forms of expression, the metaphorization of artistic language, and it became obvious appeal to traditional strata of esthetic consciousness.

For painting of Uzbekistan of the beginning of the 1990s, characterized by a wide spectrum of style models. This is one of the notable features of the art of the transitional period - a search at its core, when in a whimsical style woven kaleidoscope of different directions such as social realism, decorativism, innovation in the form of non-figurative painting, or installation solutions. This is largely due to the deepening and extension of the creative world outlooking, the desire of the authors to go beyond known standards and traditional techniques.

In general, the art of Uzbekistan of the 1990s has undergone a change of certain stylistic priorities: from accentuated attention to the traditions of the Oriental miniature that some artists tried to raise to the rank of almost the only national-true style, 
attempts to let the timid, but the avant-garde aims of the projects. Within these extreme points is the area of more moderate creative research, coming from realistic traditions, has not lost its followers in the 1990 s, as well as modernist solutions related to the search for a new philosophy of art without sharp rejection own plastic achievements of the recent past. All this polyphonic set of the art style was due to new historical realities - have opened in the last decade and a half of free plastic expression and philosophical ideas.

However the 24-year period of the development of modern art of Uzbekistan in its dynamics is ambiguous. At the beginning of the 1990s we observe a fairly clear change in the philosophy of art and radical change of stylistic principles. New developments covered most of artists. But by the mid-1990s there has been certain stagnation, all the more strange given the complete creative freedom of choice - the artists did not go beyond the already found pictorial diagrams and directions. By the end of the 1990s there is a surge of revisionist wave, are spatially innovative solutions, characterized by the understanding of new problems and the original plastic thought. Held in 2001, 2003, 2005, 2007, 2009, 2011, 2013，2015 Tashkent International Biennale of contemporary art demonstrated perspective potential of artists of the country.

With the formation of the Academy of arts of Uzbekistan the creative life have intensified. In the Central exhibition hall of the Academy one after the other are as well as personal and group exhibitions.

An important event in the development of art history and art criticism of Uzbekistan and at the same time a kind of indicator that determined their level was the release from 1998 of the magazine "SAN'AT" (the "ART") was founded in accordance with decree of the President Islam Karimov on the organization of the Academy of arts of Uzbekistan. Over the past since the founding of the journal 17 years, was released more than 65 numbers, in which published scientific and critical articles on the history of arts and modern artistic culture (including cinema, music, theater, television, etc.). The journal is published in three languages - Uzbek, Russian and English, which allows to significantly increasing the readership. The "SAN'AT" has received high praise among a wide range of domestic and foreign readers, artists, experts, scientists, art historians, critics, etc. for good printing quality and high academic and analytical level of most publications, the analysis of which shows that in the study of art history and artistic crafts have developed a more favorable picture than in the field of research of modern painting art. An art-historical science and research in the field of applied art proved to be more active and fundamental - perhaps there has been a tradition of the academic genre of researches.
Due to the increased state attention to revival of national values and established traditions of studying the everyday culture of the Uzbek people, much has been done in the 1990s in the study of folk and decorative art. A specific of the folk art, creative evolutionary character transformations in the collective work has affected the character of the research process. Over the years, (more precisely, over the last ten years) was published a number of books about the history of artistic crafts of Uzbekistan and works of applied art In the twentieth century, including monographs by such authors as E. Gul "Dialogue of cultures in the art of Uzbekistan", K. Akilova "Folk applied art of Uzbekistan of the twentieth century", I. Bogoslovskaya and L. Levteeva "Skull-caps of Uzbekistan of the XIX-XX centuries", A. Khakimov and E. Gul "Boysun. The Atlas of artistic crafts", as well as a collective work under the scientific editorship of A. Khakimov "The Atlas of crafts of Uzbekistan". Also there published albums of N. Sadykova about the national costume of Uzbekistan, Sh. Shyakubova about contemporary miniature painting, 7 albums-directory of museums of Uzbekistan, albums, catalogs of international exhibitions in Germany, Japan, France and other countries to include great material for crafts, albums, catalogs of leading artists of Uzbekistan.

One of the undoubted achievements of art should be considered the publication of the book "The new art of Uzbekistan", devoted to the study of the artistic process in Uzbekistan in the period of independence (1991-2001). This is the first fundamental work on the synthesis and analysis of the development of the national art in the new historical conditions, published also in the official language. The book was prepared by a team of the research Institute of art and is essentially a detailed history of the art of modern times. The art of Uzbekistan in the period of independence is examined in this book with objective, free from political considerations and ideological dogmas of scientific positions. At the same time all the valuable in an artistic culture that was established in previous years is regarded as an essential national cultural heritage. The processes occurring in contemporary art, examines in the context of historical transformations and social development.

However, despite the release of a significant amount of high-quality publications, there is still a clear shortage of articles and publications of analytical character. Today the development of modern graphic art, sculpture, avant-garde fine art of Uzbekistan has remained almost out of sight. When the artistic process activated, rather the favorable status of publishing opportunities, improve the printing quality of publications remains a topical problem of methodological capacity of art history and criticism in covering the matters of development 


\begin{tabular}{|c|c|c|c|c|c|c|}
\hline Impact Factor: & $\begin{array}{l}\text { ISRA (India) } \\
\text { ISI (Dubai, UAF } \\
\text { GIF (Australia) } \\
\text { JIF }\end{array}$ & $\begin{array}{r}=1.344 \\
=0.829 \\
=0.564 \\
=1.500\end{array}$ & $\begin{array}{l}\text { SIS (USA) } \\
\text { PИНЦ (Russia) } \\
\text { ESJI (KZ) } \\
\text { SJIF (Morocco) }\end{array}$ & $\begin{array}{l}=0.912 \\
=0.179 \\
=1.042 \\
=2.031\end{array}$ & $\begin{array}{l}\text { ICV (Poland) } \\
\text { PIF (India) }\end{array}$ & $\begin{array}{l}=6.630 \\
=1.940\end{array}$ \\
\hline
\end{tabular}

of fine and applied art of Uzbekistan of the XX XXI centuries.

\section{References:}

1. (2014) Konstituciya Respubliki Uzbekistan. Tashkent, Uzbekistan.

2. Karimov IA (2008) Yuksak ma"naviyat engilmas kuch. Toshkent, Uzbekiston, 2008.

3. (2003) Ideya nacional'noj nezavisimosti: osnovnye ponyatiya i principy. Tashkent, Uzbekistan.

4. (1997) Ukaz Prezidenta Respubliki Uzbekistan Islama Karimova ot 13 jan. 1997. Ob organizacii Akademii hudozhestv Uzbekistana. Available: http://art-academy.uz/akademiya/ (Accessed: 20.01.2016).

5. Garipova G (1997) Konceptual'nye tendencii razvitiya uzbekskoj literatury konca HKH nachala HKHI vekov. Available: http://www.ziyouz.uz/ru/literaturovedenie/49literaturnaya-kritika/977--i- (Accessed: 20.01.2016).

6. Mihajlichenko BS (2009) Problemy literaturovedeniya: teoriya literatury.
Monografiya. - Samarkand: SamGU, 2009. $182 \mathrm{p}$.

7. Nedoshivin G (2016) Voprosy iskusstva socialisticheskogo realizma. Available: http://www.artvek.ru/iskusstvo/ocherki26.html (Accessed: 20.01.2016)

8. Saifnazarov I, Kasymov B, Toktaev V (2012) Ideya nacional'noj nezavisimosti (uchebnoe posobie). - Tashkent, 2012. - $175 \mathrm{p}$.

9. Hakimov A (2011) Iskusstvo Uzbekistana v kontekste vremeni. Available: http://sanat.orexca.com/2011-rus/2011-22/akbar_hakimov/ (Accessed: 20.01.2016).

10. Hamidov H (1997) Istoriya duhovnoj kul'tury Uzbekistana: formirovanie i problemy razvitiya (na primere istorii uzbekskogo tradicionnogo pesennogo iskusstva). Avtoreferat dissertacii po istorii, special'nost' VAK RF 07.00.02, 1997. 